\title{
Switching of mouse spermatogonial proliferation from the c-kit receptor-independent type to the receptor-dependent type during differentiation
}

\author{
Y. Tajima ${ }^{1}$, K. Sawada ${ }^{2}$, T. Morimoto ${ }^{1}$ and Y. Nishimune ${ }^{1}$ \\ ${ }^{1}$ Research Institute for Microbial Diseases, Osaka University, Yamadaoka, Suita, Osaka 565, Japan; and \\ ${ }^{2}$ Department of Pathology, Osaka Medical College, Takatsuki, Osaka 569, Japan
}

\begin{abstract}
Testicular cells composed mostly of germ cells and immature Sertoli cells from neonatal mice 2 and 5 days old were cultured to investigate germ-cell proliferation mediated by the c-kit receptor. The addition of antibody to block the interaction of the c-kit receptor with its ligand inhibited the proliferation of cultured spermatogonia from 5-day-old mice in a dose-dependent manner, but not from that of 2-day-old mice. The addition of anti-c-kit ACK2 monoclonal antibody also inhibited the proliferation of spermatogonia from 5-day-old mutant $\mathrm{Sl}^{d} / \mathrm{Sl}^{d}$ mice but not of 5-day-old mutant $\mathrm{W}^{*} / \mathrm{W}^{0}$ mice. The results indicate that c-kit-positive type A spermatogonia in the testes of 5-day-old mice require steel factor (kit ligand) for their proliferation, whereas self-renewal and differentiation of c-kit-negative primitive type A spermatogonia in the testes of 2-day-old mice do not.
\end{abstract}

\section{Introduction}

Mutations at the murine dominant white-spotting $(W)$ and the steel (SI) loci lead to defects in haematopoiesis, melanogenesis and gametogenesis (Russell, 1979). Recent progress in the studies of these loci has demonstrated that the c-kit gene that encodes a transmembrane tyrosine kinase receptor is allelic with the $W$ locus (Chabot et al., 1988). Characterization of the growth factor binding to the c-kit receptor led to the identification of the gene encoding the steel factor (SF; the kit ligand), which is allelic with the $\mathrm{Sl}$ locus (Anderson et al., 1990; Huang et al., 1990; Williams et al., 1990; Zsebo et al., 1990).

Several severe mutations of $S l\left(S l, S^{l, g b, 8 H, 10 H, 12 H, 18 H}\right)$ have been shown by Southern blot analysis to be deletions of the gene encoding $\mathrm{SF}$, which lead to loss of function (Copeland et al., 1990). Although the Steel-Dickie allele $\left(S l^{d}\right)$ is viable and less severe, in the homozygous condition it displays all of the pleiotropic effects associated with $S l$ mutations, suggesting some residual functional activity of SF. Molecular analysis has indicated that the $S l^{d}$ allele arose as a result of an intragenic deletion, including the transmembrane domain and the carboxy terminus, which generated a secreted, biologically active SF protein product (Brannan et al., 1991; Flanagan et al., 1991). The $S^{p a n}\left(\mathrm{Sl}^{t}\right)$ mutations have normal SF coding sequences but the expression of such SF transcripts is consistently reduced in several tissues including the testis and ovary of homozygous mutant mice, suggesting that $S I^{p a n}$ affects SF expression (Huang et al., 1993). In homozygous $S \mathrm{P}^{p a n} / \mathrm{Sl}^{p a n}$ and $S \mathrm{I}^{t} / S l^{t}$ mice, males are fertile while females are sterile (Beechey et al., 1986). The $\mathrm{Sl}^{17 H}$ mutation results from a defect that causes the SF cytoplasmic domain to be read from an alternative reading

Received 7 February 1994. frame. $S l^{17 H}$ produces male sterility in the homozygous state. In $\mathrm{Sl}^{17 \mathrm{H}} / \mathrm{Sl}^{17 \mathrm{H}}$ mice, the first wave of spermatogenesis is completed, but later on sperm development is almost completely stopped leading to a depletion of differentiating germ cells by 8 weeks of age (Brannan et al., 1992).

In the testis, expression of the c-kit receptor can be observed by in situ hybridization and immunohistochemical analysis in type A spermatogonia, and remains during further spermatogonial proliferation up to the early preleptotene spermatocyte stage; it is also present on Leydig cells (Manova et al., 1990; Yoshinaga et al., 1991). We have reported that the $W$ and $\mathrm{Sl}$ genes play some important roles in spermatogenesis (Nishimune et al., 1980; Koshimizu et al., 1991; Sawada et al., 1991; Tajima et al., 1991a) and have demonstrated that Sertoli cells are a main producer of biologically active SF in a membrane-bound form (Tajima et al., 1991b). Furthermore, cAMP analogues stimulate an increase in the amount of mRNA (Rossi et al., 1993) and biologically active SF (Tajima et al., 1993) produced in cultured primary mouse Sertoli cells. Injection of an antagonistic anti-c-kit antibody (ACK2 $\mathrm{mAb}$ ) in vivo results in a loss of differentiating type A spermatogonia, but has no effect on the transition of intermediate spermatogonia to type B spermatogonia and on spermatocytes (Yoshinaga et al., 1991).

SF is produced from two alternatively spliced mRNAs as transmembrane proteins that may function as cell-associated proteins or may be proteolytically processed to produce the soluble form of SF (Flanagan et al., 1991; Huang et al., 1992). Both the soluble and membrane-bound forms of SF are biologically active. The membrane-bound form is more effective in promoting the survival and proliferation of primordial germ cells (Dolci et al., 1991; Matsui et al., 1991). The forms of SF mRNA present in the testes suggest that the 
membrane-bound form of SF predominates in 5-day-old mice (Manova et al., 1993). In contrast, the soluble form of SF can promote DNA synthesis in type A spermatogonia (Rossi $e t$ al, 1993). However, we previously noted that cell-cell contact is indispensable for the activity of SF produced by Sertoli cells to stimulate c-kit receptors on mast cells, that SF appears to be associated with the cell surface of Sertoli cells (Tajima et al., 1991b), and that SF presumably also stimulates the growth and differentiation of germ cells.

In the present study, we investigated the role of the c-kit receptor and $\mathrm{SF}$ in spermatogonial proliferation and differentíation in vitro. Our results demonstrate that proliferation of c-kit-positive type A spermatogonia require SF produced by Sertoli cells but that self-renewal and differentiation of c-kitnegative primitive type $\mathrm{A}$ spermatogonia to c-kit-positive spermatogonia is independent of $\mathrm{c}-\mathrm{kit}$ and $\mathrm{SF}$.

\section{Materials and Methods}

\section{Cell preparation}

C57BL/6 mice $\left(S^{d} /+, W^{j} /+\right.$ and ++$)$ were raised in our animal centre. Sertoli cells and germ cells were isolated from 2-day-old and 5-day-old mice, as reported by Maekawa and Nishimune (1991). Approximately $5 \times 10^{4}$ cells in $250 \mu \mathrm{l}$ of minimum essential medium (Nissui Pharmaceutical Co., Tokyo) supplemented with $10 \%$ fetal calf serum were plated in each of the 16 chambers of a tissue culture slide (base area, $0.3 \mathrm{~cm}^{2}$ per chamber; Nunc, Naperville, IL).

\section{Antibodies}

Germ cells were detected on the slides by immunoperoxidase staining using an anti-testicular germ cell TRA-98 monoclonal antibody $(\mathrm{mAb})$ that recognizes exclusively germ cell nuclei from early spermatogonia to round spermatids (K. Sawada, unpublished). Anti-c-kit ACK2 mAb, which recognizes the extracellular domain of the murine c-kit receptor and antagonizes the interaction of the receptor with its ligand (Nishikawa et al., 1991), was supplied by S-I. Nishikawa (Kyoto University Medical School, Kyoto).

\section{Cell culture and $\left.{ }^{3} H\right]$ thymidine labelling}

Cultured testicular cells were maintained at $32.5^{\circ} \mathrm{C}$ in an incubator under an atmosphere of humidified $5 \% \mathrm{CO}_{2}$. Sixteen hours after plating, antibodies ( $\mathrm{ACK} 2 \mathrm{mAb}$ and a rat antibody IgG2b, as control) were added to the culture medium. After $24 \mathrm{~h}$ the cultures were pulsed for $4 \mathrm{~h}$ with $\left[{ }^{3} \mathrm{H}\right]$ thymidine at $1 \mu \mathrm{Ci} \mathrm{ml}{ }^{-1}$. Cells were fixed in cold acetone for $5 \mathrm{~min}$ and processed for immunostaining and autoradiography, as described below.

\section{Immunostaining}

The germ cells were immunostained by incubating the cultured slides with TRA-98 mAb at room temperature for $1 \mathrm{~h}$. To stain for the c-kit receptor, the cultured slides were incubated with purified $10 \mu \mathrm{g}$ ACK2 $2 \mathrm{mAb}$ antibody $\mathrm{ml}^{-1}$ in phosphate buffer at $4^{\circ} \mathrm{C}$ overnight. Antibody binding to cells was detected using the avidin-biotin-peroxidase complex with the Vectastain elite $A B C$ kit (Vector Laboratories, Burlingame, CA) according to the manufacturer's recommendation, and finally immersing in diaminobenzidine substrate solution.

\section{Autoradiography}

Autoradiograms were prepared by dipping the slides into NR-M2 emulsion. After exposure for 7 days, the slides were developed, fixed and mounted for examination under a microscope.

\section{Results}

Expression of the c-kit receptor on testicular germ cells cultured in vitro

Germ cells and supporting cells from 2-day-old and 5-dayold mice were cultured for $24 \mathrm{~h}$, and immunostained with TRA-98 mAb and ACK2 mAb. As shown in Fig. 1, round cells from both 2-day-old and 5-day-old testes were stained with TRA-98 mAb; frequently, two cells were connected. In contrast, flat adherent cells that spread out on the slides were not immunostained. These results identified the round cells as germ cells or spermatogonia and the flat cells as immature Sertoli cells. Furthermore, many germ cells from 5 -day-old testes were c-kit-positive, whereas few positive cells were detected in the culture from 2-day-old testes (Fig. 1), indicating that the c-kit-positive spermatogonia in 5-day-old testes derived from c-kit-negative germ cells in 2-day-old testes.

\section{Effects of the antagonistic anti-c-kit $A C K 2 m A b$ on the proliferation of spermatogonia in vitro}

The function of the c-kit receptor in the proliferation of spermatogonia in vitro was investigated with ACK2 $\mathrm{mAb}$. After plating the testicular cells from 2-day-old and 5-day-old mice and treating them with various concentrations of ACK2 $\mathrm{mAb}\left(2.5-50 \mu \mathrm{g} \mathrm{ml}^{-1}\right)$ for $24 \mathrm{~h}$, they were labelled with $\left[{ }^{3} \mathrm{H}\right]$ thymidine. The number of labelled germ cells stained with TRA-98 mAb was counted. The proportion of $\left[{ }^{3} \mathrm{H}\right]$ thymidine-labelled germ cells from 5-day-old mice decreased significantly $(P<0.01)$ with the addition of $5 \mu \mathrm{g}$ ACK $2 \mathrm{mAb} \mathrm{ml}{ }^{-1}$ from $40 \%$ to $25 \%$, but not from those of 2-day-old mice (Fig. 2). The class-matched control antibody at $10 \mu \mathrm{g} \mathrm{ml}^{-1}$ had no effect (Fig. 2). As germ cells from 5-day-old mice contain both c-kit-positive and c-kitnegative cells, $22 \%$ of germ cells from 5 -day-old mice still proliferated even at the highest concentration of antibody used (50 $\mu \mathrm{g} \mathrm{ml}^{-1}$ ) (Fig. 2).

The role of the c-kit receptor on the proliferation of spermatogonia was investigated further by studying the effect of the ACK2 mAb differentially on c-kit-positive or c-kitnegative germ cells. The proportion of $\left[{ }^{3} \mathrm{H}\right]$ thymidine-labelled c-kit-positive germ cells from 5-day-old mice decreased in 

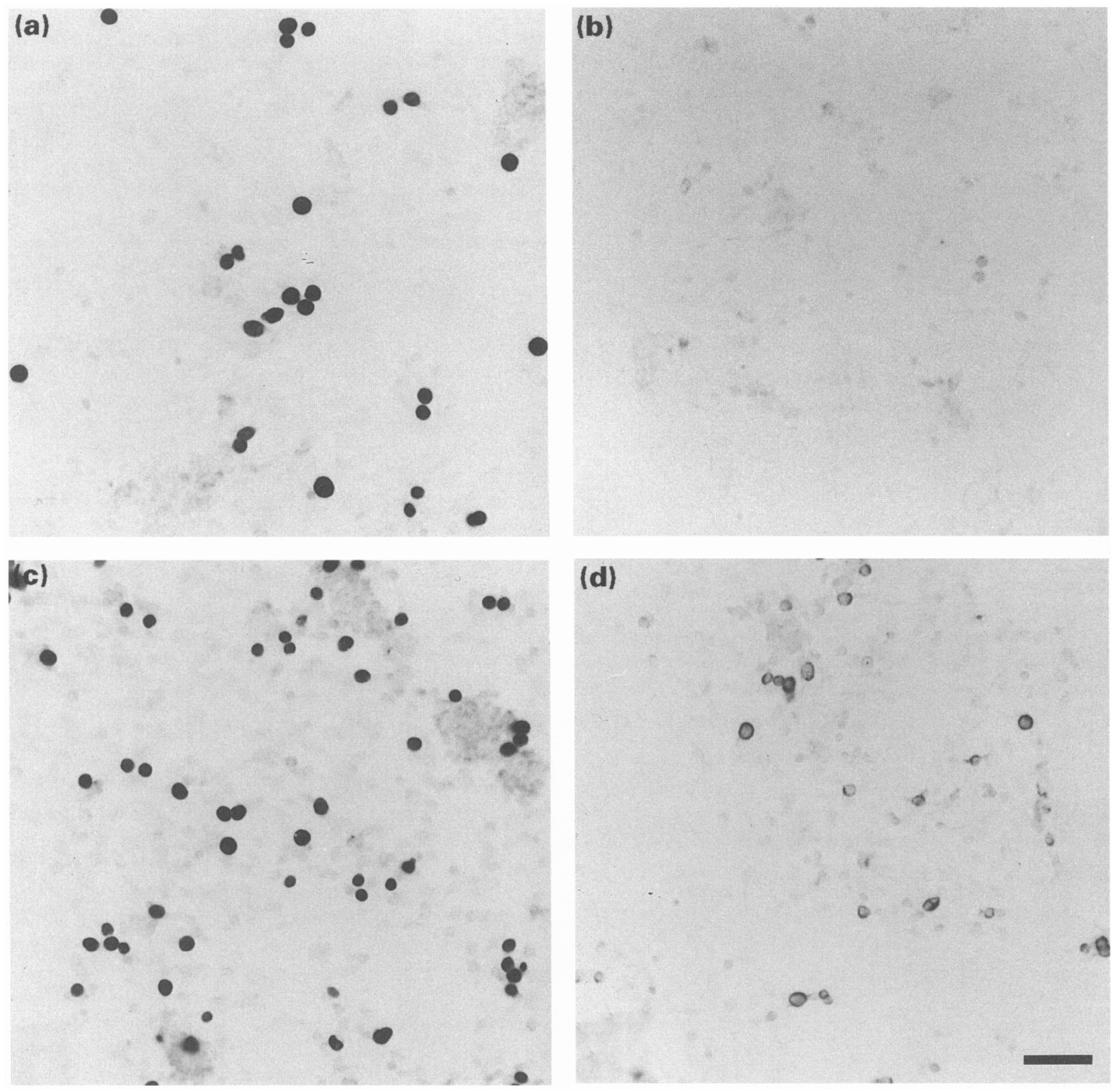

Fig. 1. Expression of the c-kit receptor in mouse testicular cell cultures. Testicular cell cultures from (a, b) 2-day-old and (c, d) 5-day-old mice were immunostained for germ cells with ( $a, c)$ TRA-98 monoclonal antibody (mAb) and for c-kit receptor with (b, d) ACK2 mAb. Scale bar represents $50 \mu \mathrm{m}$.

response to the ACK2 mAb (5 $\mu \mathrm{g} \mathrm{ml}^{-1}$ ) from $42 \%$ to $15 \%$ compared with no decrease in c-kit-negative germ cells. These results indicated that the majority of c-kit-positive germ cells in 5 -day-old testes proliferated in a manner dependent on the c-kit receptor.

Existence and proliferation of spermatogonia in mutant $\mathrm{Sl}^{\mathrm{d}} / \mathrm{Sl}{ }^{\mathrm{d}}$ and $\mathrm{W}^{\mathrm{v}} / \mathrm{W}^{\mathrm{v}}$ mouse testes and the effects of anti-c-kit ACK2 $m A b$ on their proliferation in vitro

Although there are germ cells in the neonatal testes of mutant $S I^{d} / S l^{d}$ and $W^{v} / W^{v}$ mice, their number is small com- pared with that of the testes of wild-type $(+/+)$ mice. However, the spermatogonia derived from both $S l^{d} / S l^{d}$ and $W^{v} / W^{v}$ mutant mice can proliferate in vitro in a similar way to control $+/+$ spermatogonia (Table I). Furthermore, some of the spermatogonia from 5-day-old $\mathrm{Sl}^{d} / S l^{d}$ and $\mathrm{W}^{*} / \mathrm{W}^{v}$ mice were immunofluorescence-stained with anti-c-kit ACK2 mAb, indicating that germ cells from the testes of 5-day-old $S I^{d} / S l^{d}$ and $W^{*} / W^{o}$ mice differentiated into c-kit-positive cells (data not shown). To investigate whether the c-kit receptor expressed on $S S^{d} / S^{d}$ and $W^{v} / W^{0}$ spermatogonia affects proliferation in vitro, we studied the effect of the anti-c-kit ACK2 $\mathrm{mAb}$ on the uptake of $\left[{ }^{3} \mathrm{H}\right]$ thymidine. As shown in Table 1 , the number of labelled spermatogonia in $+/+$ and $S l^{d} / S l^{d}$ mice decreased when ACK2 


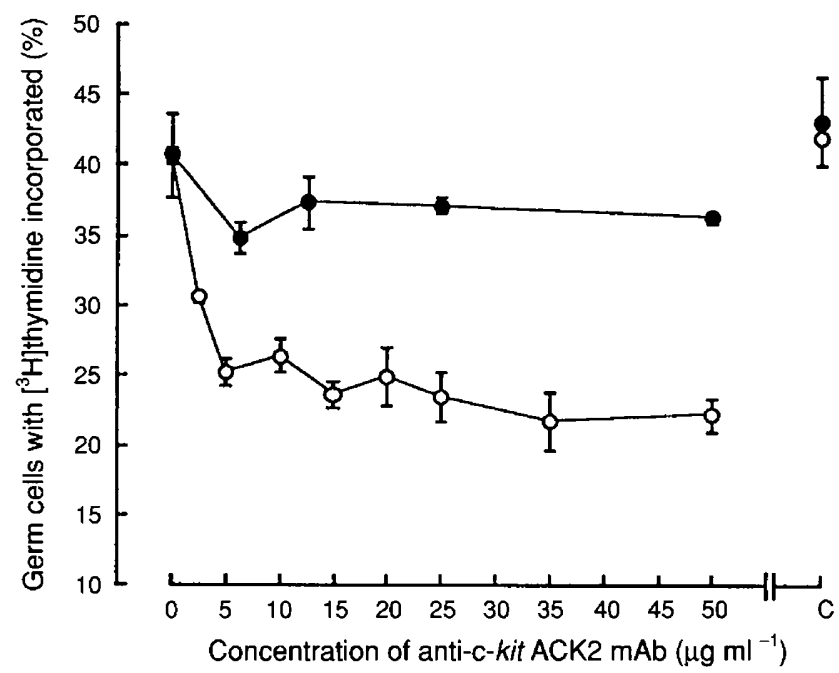

Fig. 2. Effects of antagonistic anti-c-kit ACK2 monoclonal antibody $(\mathrm{mAb})$ on the proliferation of mouse spermatogonia in vitro. The dose-dependent effect of $\mathrm{ACK} 2 \mathrm{mAb}$ on the proliferation of spermatogonia was tested by adding various concentrations of ACK2 $\mathrm{mAb}$ and the cultures were incubated for $24 \mathrm{~h}$ followed by the addition of $\left[{ }^{3} \mathrm{H}\right]$ thymidine for $4 \mathrm{~h}$. The uptake of $\left[{ }^{3} \mathrm{H}\right]$ thymidine in germ cells from 2 -day-old testes $(\bullet)$ and 5 -day-old testes ( $)$ ) stained with TRA-98 mAb were then counted. The reported values are the percentages of labelled germ cell nuclei observed out of more than 600 nuclei. Data represent means \pm SEM of four independent cultures. C: control rat, $10 \mu \mathrm{g} \mathrm{IgG2b}$ antibody $\mathrm{ml}^{-1}$.

$\mathrm{mAb}\left(25 \mu \mathrm{g} \mathrm{ml}^{-1}\right)$ was added, although the total number of spermatogonia was small in the mutant mice. In contrast, the proliferation of spermatogonia from 5 -day-old $W^{v} / W^{*}$ mutant mice, which have a defective c-kit receptor owing to a missense mutation but a normal size and cell surface expression (Nocka et al., 1990), was not inhibited by ACK2 mAb (Table 1). These results support the notion that (i) some of the $+1+$ and $S l^{d} / S l^{d}$ spermatogonia differentiated into c-kit-positive spermatogonia in 5-day-old testes, which then proliferated in a c-kit-SFdependent manner (Table 1), and (ii) the differentiation step from c-kit-negative to c-kit-positive spermatogonia is independent of c-kit and SF, as the testes of both $\mathrm{Sl}^{d} / \mathrm{Sl}^{d}$ and $\mathrm{W}^{*} / \mathrm{W}^{o}$ 5 -day-old mutant mice contain c-kit-positive germ cells.

\section{Discussion}

In mice and rats there are four generations of type $A$ spermatogonia $\left(A_{1}-A_{4}\right)$ and one generation each of intermediate (In) and type B spermatogonia (Monesi, 1962; Clermont and Bustos-Obregon, 1968). Kluin and de Rooij (1981) reported that at day 3 after birth the mouse testes contain solely type A spermatogonia, at day 4 the first intermediate spermatogonia appear, and at days 5 and 6 the first type B spermatogonia and primary spermatocytes are observed. Although we cannot analyse the type of spermatogonia of cultured germ cells of 5-day-old testes, the culture we used was designed to contain both differentiated c-kit-positive and undifferentiated c-kit-negative spermatogonia. The inhibitory effect of anti-c-kit antibody on proliferation was observed in the population of c-kit-positive germ cells but not in c-kitnegative cells. However, some of the c-kit-positive cells take up $\left[{ }^{3} \mathrm{H}\right]$ thymidine even in the presence of an excess amount of blocking antibody. This may be due to the action of other paracrine growth factors; alternatively, Sertoli cells expressing membrane-bound SF may form a tight association with germ cells that blocking antibodies cannot inhibit.

Our data also demonstrate that differentiation of spermatogonia proceeds from 2-day-old c-kit-negative germ cells to 5-day-old c-kit-positive germ cells. Approximately half of the germ cells in 5-day-old mice are c-kit positive. However, this differentiation step does not seem to require c-kit receptor stimulation, as the testes of both $S l^{d} / S l^{d}$ and $W^{v} / W^{v}$ 5-day-old mice contain c-kit-positive germ cells (the $\mathrm{Sl}^{d} / \mathrm{Sl}^{d}$ mutant is known to produce soluble $S F$, and the kinase activity of $W^{0} / W^{0}$ c-kit receptor is only partially impaired in vitro; Nocka et al., 1990). From some experiments it might be hypothesized that the $\mathrm{Sl}^{d} \mathrm{SF}$ protein product sustains cell migration but not cell proliferation; consequently, the cell membrane form of SF may play a critical role in the proliferative response of cells to $c-k i t$ (McCoshen and McCallion, 1975; Silvers, 1979).

$\mathrm{Sl}^{d} / \mathrm{Sl}^{d}$ fibroblasts and $\mathrm{Sl}^{d} / \mathrm{Sl}^{d}$ Sertoli cells do not support the proliferation and maintenance of bone marrow mast cells in the absence of interleukin 3 (IL-3), in contrast to wild-type cells (Fujita et al., 1989; Tajima et al., 1991b). Although the testes of $W^{*} / W^{*}$ mice contain c-kit-receptor-positive germ cells (data not shown), and the size and cell surface expression of the c-kit receptor kinase and the antigenicity detected by ACK2 mAb

Table 1. Effects of ACK2 monoclonal antibody $(\mathrm{mAb})$ on the proliferation of germ cells in the testes of 5-day-old wild-type, $\mathrm{Sl}^{d} / \mathrm{Sl}^{d}$, and $W^{*} / W^{v}$ mice

Fraction of germ cells in S phase $(\%)^{a}$

\begin{tabular}{lcccc} 
Genotype & Without ACK2 mAb & With ACK2 mAb $\left(25 \mu \mathrm{g} \mathrm{ml}{ }^{-1}\right)$ & Without ACK2 mAb & With ACK2 mAb $(5 \mu \mathrm{g} m \mathrm{ml}$ \\
\hline${ }^{+}$ & $42.3 \pm 0.8$ & $27.5 \pm 1.8(35)^{*}$ & $40.7 \pm 0.6$ & $25.1 \pm 1.0(38)^{*}$ \\
$S^{d d} / S^{d}$ & $39.1 \pm 2.2$ & $23.4 \pm 2.0(40)^{*}$ & $44.2 \pm 3.2$ & $33.6 \pm 3.8(24)$ \\
$W^{*} / W^{*}$ & $\mathrm{NT}$ & $\mathrm{NT}$ & $37.8 \pm 1.4$ & $39.2 \pm 1.4(\mathrm{~N})$
\end{tabular}

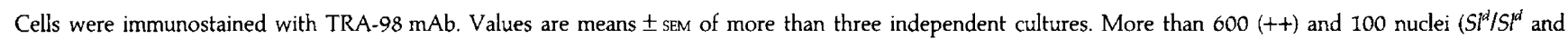
$\left.W^{v} / W^{v}\right)$ were observed. Percentage inhibition is shown in parentheses.

N: no inhibition; NT: not tested.

a Percentages of labelled germ cells that incorporated $\left[{ }^{3} \mathrm{H}\right]$ thymidine after $24 \mathrm{~h}$ of culture with or without ACK2 mAb.

$* P<0.01$ (Student's $t$ test) compared with the value when no antibody was added. 
are not affected by the mutation (Nocka et al., 1990), no effect of ACK 2 on germ cell proliferation was observed in 5-day-old $W^{*} / W^{\circ}$ mice despite the fact that no further proliferation and differentiation of germ cells could be observed in this mutant mouse. Furthermore, the proliferation and differentiation of spermatogonia into c-kit-positive cells in the testes of 5-dayold $+l+$ and $\mathrm{Sl}^{d} / \mathrm{Sl}^{d}$ mice seems to require c-kit receptor stimulation. Taking the results from these two mutants together, the signal transduction of the c-kit receptor appears to regulate the proliferation and differentiation of germ cells in the testes of 5-day-old mice.

In the testes of mutant $S P^{p a n} / S P^{p a n}$ mice the amount of SF expression is reduced, but this reduction does not have appreciable effects on spermatogenesis and male fertility. It may be that SF is not limiting in spermatogenesis and that the amounts expressed in $S P^{p a n} / S l^{p a n}$ mice are sufficient to maintain spermatogonial proliferation and normal fertility, in contrast to oogenesis where the amount of SF is limiting. Thus, the demand for stimulation by SF in the testes does not seem to be so severe as in other cell systems such as melanocytes, oocytes or mast cells. In some cases, c-kit receptor stimulation seems to be more critical in the differentiation and proliferation of primordial germ cells than in spermatogenesis (Koshimizu et al., 1992), whereas in other cases, such as in $W / W^{*}$ or $W^{*} / W^{*}$ mice where the gonocytes in testes cannot differentiate, primordial germ cells can differentiate into gonocytes or spermatogonia.

The SF cytoplasmic tail may have an important, as yet undefined, function that is impaired in $\mathrm{Sl}^{17 \mathrm{H}}$ and $\mathrm{Sl}^{d}$ mice. This could involve a feedback or signalling mechanism normally transmitted through the SF cytoplasmic tail upon interaction with c-kit-expressing cells. The germ cells could affect some biological function of Sertoli cells (Jegou, 1991), although the mechanism of germ-cell-mediated stimulation of Sertoli cells has not been identified as involving interactions between the $c$-kit receptor and SF. This notion is supported by the fact that nerve growth factor and tumour necrosis factor $\alpha$ are produced in germ cells while their receptors are synthesized on Sertoli cells, suggesting that germ cells have direct effects on Sertoli cells (Ayer-Le Lievre et al., 1988; De et al., 1993).

The factor that induces the differentiation step from c-kitnegative to c-kit-positive germ cells is unknown. Evidence from several observations has shown that the testis is an especially rich source of growth factors (Bellvé and Zheng, 1989). With respect to the paracrine action of some intratesticular factors, the roles of inhibin and activin as spermatogonial regulators have been investigated using different experimental approaches (van Dissel-Emiliani et al., 1989; Mather et al., 1990). It has also been proposed that IL-1 $\alpha$ may act as a spermatogonial mitogen on stage-specific DNA synthesis in segments of seminiferous tubules cultured in vitro (Parvinen et al., 1991). These testicular growth factors may act as autocrine and paracrine modulators of male gonadal function, but their precise role in the regulation of germ cell proliferation has yet to be defined.

The authors thank Nishikawa of Kyoto University for the gift of $\mathrm{ACK} 2 \mathrm{mAb}$ and P. Besmer of Cornell University Graduate School of Medical Science, New York for comments on this manuscript. This work was supported by grants from the Ministry of Education, Science and Culture of Japan.

\section{References}

Anderson DM, Lyman SD, Baird A, Wignall JM, Eisenman J, Rauch C, March CJ, Boswell HS, Gimpel SD, Cosman D and Williams DE (1990) Molecular cloning of mast cell growth factor, a hematopoietin that is active in both membrane bound and soluble forms Cell 63 235-243

Ayer-Le Lievre C, Olson L, Ebendal T, Hallbook F and Persson H (1988) Nerve growth factor mRNA and protein in the testis and epididymis of mouse and rat Proceedings of the National Academy of Sciences, USA 85 2628-2632

Beechey CV, Loutit JF and Searle AG (1986) Panda, a new steel allele Mouse News Letters $\mathbf{7 3} 17$

Bellvé AR and Zheng W (1989) Growth factors as autocrine and paracrine modulators of male gonadal functions Journal of Reproduction and Fertility $\mathbf{8 5}$ $771-793$

Brannan CI, Lyman SD, Williams DE, Eisenman J, Anderson DM, Cosman D, Bedell MA, Jenkins NA and Copeland NG (1991) Steel-Dickie mutation encodes a c-kit ligand lacking transmembrane and cytoplasmic domains Proceedings National Academy of Sciences USA 88 4671-4674

Brannan CI, Bedell MA, Resnick JL, Eppig JJ, Handel MA, Williams DE, Lyman SD, Donovan PJ, Jenkins NA and Copeland NG (1992) Developmental abnormalities in Steel17H mice result from a splicing defect in the steel factor cytoplasmic tail Genes and Development 6 1832-1842

Chabot B, Stephenson DA, Chapman VM, Besmer P and Bernstein A (1988) The proto-oncogene $c-k i t$ encoding a transmembrane tyrosine kinase receptor maps to the mouse $W$ locus Nature $33588-89$

Clermont $Y$ and Bustos-Obregon E (1968) Re-examination of spermatogonial renewal in the rat by means of seminiferous tubule mounted 'in toto' American Joumal of Anatomy 122 237-248

Copeland NG, Gilbert DJ, Cho BC, Donovan PJ, Jenkins NA, Cosman D, Anderson D, Lyman SD and Williams DE (1990) Mast cell growth factor maps near the steel locus on mouse chromosome 10 and is deleted in a number of steel alleles Cell 63 175-183

De SP, Chen HL, Pace JL, Hunt JS, Terranova PF and Enders GC (1993) Expression of tumor necrosis factor- $\alpha$ in mouse spermatogenic cells Endocrinology 133 389-396

Dolci S, Williams DE, Ernst MK, Resnick JL, Brannan CI, Lock LF, Lyman SD, Boswell HS and Donovan PJ (1991) Requirement for mast cell growth factor for primordial germ cell survival in culture Nature 352 809-811

Flanagan JG, Chan DC and Leder P (1991) Transmembrane form of the kit ligand growth factor is determined by alternative splicing and is missing in the Sid mutant Cell 64 1025-1035

Fujita J, Onoue H, Ebi Y, Nakayma H and Kanakura Y (1989) In vitro duplication and in vivo cure of mast-cell deficiency of $S / / S l^{d}$ mutant mice by cloned 3T3 fibroblasts Proceedings National Academy of Sciences USA 86 2888-2891

Huang E, Nocka K, Beier DR, Chu TY, Buck J, Lahm HW, Wellner D, Leder P and Besmer P (1990) The hematopoietic growth factor KL is encoded by the SI locus and is the ligand of the c-kit receptor, the gene product of the $W$ locus Cell $63225-233$

Huang EJ, Nocka KH, Buck J and Besmer P (1992) Differential expression and processing of two cell-associated forms of the kit ligand KL-1 and KL-2 Molecular Biology of the Cell 3 349-362

Huang EJ, Manova K, Packer AI, Sanchez S, Bachvarova RF and Besmer P (1993) The murine steel panda mutation affects kit ligand expression and growth of early ovarian follicles Developmental Biology 157 100-109

Jegou B (1991) Spermatids are regulators of Sertoli cell function Annals of the New York Academy of Sciences 637 340-353

Kluin PM and de Rooij DG (1981) A comparison between the morphology and cell kinetics of gonocytes and adult type undifferentiated spermatogonia in the mouse International Joumal of Andrology 4 475-493

Koshimizu U, Sawada K, Tajima Y, Watanabe D and Nishimune Y (1991) White-spotting mutations affect the regenerative differentiation of testicular germ cells: demonstration by experimental cryptorchidism and its surgical reversal Biology of Reproduction 45 642-648

Koshimizu U, Watanabe D, Tajima $Y$ and Nishimune $Y$ (1992) Effects of W (c-kit) gene mutation on gametogenesis in male mice agametic tubular segments in Wf/Wf testes Development 114 861-867

McCoshen JA and McCallion DJ (1975) A study of the primordial germ cells during their migratory phase in steel mutant mice Experientia 31 589-590 
Maekawa M and Nishimune Y (1991) In-vitro proliferation of germ cells and supporting cells in the neonatal mouse testis Cell and Tissue Research 265 551-554

Manova K, Nocka K, Besmer P and Bachvarova RF (1990) Gonadal expression of $c-k i t$ encoded at the $W$ locus of the mouse Development 110 1057-1069

Manova K, Huang EJ, Angeles M, De LV, Sanchez S, Pronovost SM, Besmer P and Bachvarova RF (1993) The expression pattern of the $c-k i t$ ligand in gonads of mice supports a role for the c-kit receptor in oocyte growth and in proliferation of spermatogonia Developmental Biology 157 85-99

Mather JP, Attie K, Woodruff T, Rice G and Phillips D (1990) Activin stimulates spermatogonial proliferation in germ-Sertoli cell cocultures from immature rat testis Endocrinology 127 3206-3214

Matsui Y, Toksoz D, Nishikawa S, Nishikawa S-I, Williams D, Zsebo K and Hogan BLM (1991) Effect of steel factor and leukaemia inhibitory factor on primordial germ cells in culture Nature 353 750-752

Monesi V (1962) Autoradiographic study of DNA synthesis and the cell cycle in spermatogonia and spermatocytes of mouse testis using tritiated thymidine Journal of Cell Biology 14 I-18

Nishikawa S, Kusakabe M, Yoshinaga K, Ogawa M, Hayashi S, Kunisada T, Era T, Sakakura T and Nishikawa S-I (1991) In utero manipulation of coat color formation by a monoclonal anti-c-kit antibody: two distinct waves of c-kit dependency during melanocyte development EMBO Joumal 10 2111-2118

Nishimune Y, Haneji T and Kitamura Y (1980) The effects of steel mutation on testicular germ cell differentiation Journal of Cellular Physiology 105 137-14I

Nocka K, Tan CJ, Chiu E, Chu YT, Traktman P and Besmer P (1990) Molecular bases of dominant negative and loss of function mutations at the murine c-kit/white spotting locus: $\mathrm{W}^{37}, \mathrm{~W}^{\mathrm{v}}, \mathrm{W}^{41}$ and $\mathrm{W} E M B O$ Journal 9 1805-1813

Parvinen M, Soder O, Mali P, Froysa B and Ritzen EM (1991) In vitro stimulation of stage-specific deoxyribonucleic acid synthesis in rat seminiferous tubule segments by interleukin-1a Endocrinology 129 1614-1621

Rossi P, Dolci S, Albanesi C, Grimaldi P, Ricca R and Geremia R (1993) Follicle-stimulating hormone induction of steel factor (SLF) mRNA in mouse
Sertoli cells and stimulation of DNA synthesis in spermatogonia by soluble SLF Developmental Biology 155 68-74

Russell, ES (1979) Hereditary anemias of the mouse: a review for geneticists Advanced Genetics 20 357-459

Sawada K, Sakamaki K and Nishimune Y (1991) Effect of the W mutation, for white belly spot, on testicular germ cell differentiation in mice Journal of Reproduction and Fertility 93 287-294

Silvers WK (1979) White spotting: Piebald, Lethal Spotting and Belted. In The Coat Colors of Mice pp 185-199. Springer-Verlag, New York

Tajima $Y$, Sakamaki K, Watanabe D, Koshimizu U, Matsuzawa $T$ and Nishimune $Y$ (1991a) Steel-Dickie ( $\mathrm{Sl}^{\mathrm{d}}$ ) mutation affects both maintenance and differentiation of testicular germ cells in mice Joumal of Reproduction and Fertility $91441-449$

Tajima Y, Onoue H, Kitamura Y and Nishimune Y (1991b) Biologically active kit ligand growth factor is produced by mouse Sertoli cells and is defective in Sl $^{d}$ mutant mice Development 113 1031-1035

Tajima Y, Nishina Y, Koshimizu U, Jippo T, Kitamura Y and Nishimune Y (1993) Effects of hormones, cyclic AMP analogues, and growth factors on steel factor (SF) production in mouse Sertoli cell cultures Journal of Reproduction and Fertility 99 571-575

van Dissel-Emiliani FMF, Grootenhuis AJ, de Jong FH and de Rooij DG (1989) Inhibin reduces spermatogonial numbers in testes of adult mice and Chinese hamsters Endocrinology 188 32-37

Williams DE, Eisenman J, Baird A, Rauch C, Van NK, March CJ, Park LS, Martin U, Mochizuki DY, Boswell HS, Burgess GS, Cosman D and Lyman SD (1990) Identification of a ligand for the c-kit proto-oncogene Cell 63 167-174

Yoshinaga K, Nishikawa S, Ogawa M, Hayashi S, Kunisada T, Fujimoto T and Nishikawa S-I (1991) Role of c-kit in mouse spermatogenesis: identification of spermatogonia as a specific site of c-kit expression and function Development $113689-699$

Zsebo KM, Williams DA, Geissler EN, Broudy VC, Martin FH, Atkins HL, Hsu RY, Birkett NC, Okino KH, Murdock DC, Jacobsen FW, Langley KE, Smith KA, Takeishi T, Cattanach BM, Galli SJ and Suggs SV (1990) Stem cell factor is encoded at the Sl locus of the mouse and is the ligand for the c-kit tyrosine kinase receptor Cell 63 213-224 